\title{
The relationship between depressive symptoms and family functioning in institutionalized elderly*
}

\author{
RELAÇÃO ENTRE SINTOMAS DEPRESSIVOS E A FUNCIONALIDADE FAMILIAR DE \\ IDOSOS INSTITUCIONALIZADOS
}

\author{
RELACIÓN ENTRE SÍNTOMAS DEPRESIVOS Y FUNCIONALIDAD FAMILIAR EN \\ ADULTOS MAYORES INSTITUCIONALIZADOS
}

Simone Camargo de Oliveira ${ }^{1}$, Ariene Angelini dos Santos ${ }^{2}$, Sofia Cristina lost Pavarini ${ }^{3}$

\begin{abstract}
The present study aimed to investigate the relationship between family functioning and depressive symptoms among institutionalized elderly. This is a descriptive, cross-sectional study of quantitative character. A total of 107 institutionalized elderly were assessed using a sociodemographic questionnaire, the Geriatric Depression Scale (to track depressive symptoms) and the Family APGAR (to assess family functioning). The correlation coefficient of Pearson's, the chi-square test and the crude and adjusted logistic regression were used in the data analysis with a significance level of $5 \%$. The institutionalized elderly with depressive symptoms were predominantly women and in the age group of 80 years and older. Regarding family functioning, most elderly had high family dysfunctioning (57\%). Family dysfunctioning was higher among the elderly with depressive symptoms. There was a significant correlation between family functioning and depressive symptoms. The conclusion is that institutionalized elderly with dysfunctional families are more likely to have depressive symptoms.
\end{abstract}

\section{RESUMO}

$\mathrm{O}$ presente estudo objetivou verificar a relação entre funcionalidade familiar e sintomas depressivos de idosos institucionalizados. Trata-se de um estudo descritivo, transversal, de caráter quantitativo. Foram avaliados 107 idosos institucionalizados, utilizando-se questionário de caracterização sociodemográfica, a Escala de Depressão Geriátrica (rastrear sintomas depressivos) e o APGAR de família (avaliar a funcionalidade familiar). $O$ coeficiente de correlação de Pearson, o teste qui-quadrado e a Regressão Logística bruta e ajustada foram utilizados na análise dos dados, com nível de significância de 5\%. Os idosos institucionalizados com sintomas depressivos eram predominantemente mulheres e estavam inseridos na faixa etária de 80 anos e mais. Com relação à funcionalidade familiar, a maioria dos idosos apresentou elevada disfunção familiar (57\%). A disfunção familiar foi maior entre os idosos com sintomas depressivos. Houve correlação significativa entre a funcionalidade familiar e os sintomas depressivos. Conclui-se que idosos institucionalizados com famílias disfuncionais apresentam maiores chances de possuir sintomas depressivos.

\section{DESCRITORES}

Idoso

Depressão

Relações familiares

Enfermagem geriátrica

Saúde do idoso institucionalizado.

\section{RESUMEN}

El presente estudio tuvo como objetivo investigar la relación entre la funcionalidad familiar con los síntomas depresivos de adultos mayores institucionalizados. Corresponde a un estudio descriptivo transversal de carácter cuantitativo. Fueron evaluados 107 sujetos de edad avanzada por medio de un cuestionario sociodemográfico, la Escala de Depresión Geriátrica (para identificar síntomas depresivos) y APGAR Familiar (para evaluar el funcionamiento familiar). Para el análisis de datos se utilizó el coeficiente de correlación de Pearson, chi cuadrado y regresión logística cruda y ajustada, con un nivel de significancia del $5 \%$. Los adultos mayores con síntomas depresivos eran predominantemente mujeres y se insertaron en el grupo de edad de 80 años y más. Con respecto a la funcionalidad familiar, la mayoría de las personas mayores presentaban alta disfunción familiar (57\%). La disfunción familiar es mayor en los adultos mayores con síntomas depresivos. No hubo correlación significativa entre el funcionamiento familiar y síntomas depresivos. Se concluye que los adultos mayores institucionalizados con familias disfuncionales son más propensos a tener síntomas depresivos.

\section{DESCRIPTORES}

Anciano

Depresión

Relaciones familiares

Enfermería geriátrica

Salud del anciano institucionalizado.

* Extracted from the thesis "Funcionalidade familiar: um estudo com idosos institucionalizados", Universidade Federal de São Carlos, 2012. ${ }^{1}$ PhD student in Health Sciences, Faculdade de Enfermagem, Universidade Estadual de Campinas, SP, Brazil. sicamargoo@yahoo.com.br ${ }^{2}$ PhD student in Health Sciences, Faculdade de Enfermagem, Universidade Estadual de Campinas, SP, Brazil. ${ }^{3}$ Associate Professor, Departamento de Gerontologia, Universidade Federal de São Carlos, SP, Brazil. 


\section{INTRODUCTION}

Brazil is going through a fast and intense process of population aging. According to the World Bank ${ }^{(1)}$, the elderly population in the next four decades will increase from less than 20 million in 2010 to approximately 65 million in 2050.

Due to the process of aging population, the increase in chronic health conditions and the need for specialized care, the demand for Long-Term Nursing Homes - (LT$\mathrm{NHs)}$ tends to increase ${ }^{(2)}$.

A major concern in the settings of institutionalization of the elderly is the high prevalence of depressive symptoms among its residents. Depression in the elderly is more common among institutionalized elderly than among those living with their families. A study shows that $35 \%$ of nursing home residents may suffer from depressive symptoms ${ }^{(3)}$. The World Health Organization ${ }^{(4)}$ considered severe depression as the main cause of disability worldwide. Ranks fourth among the ten leading causes of disease and, according to projections, will occupy the second place in the next 20 years.

It is known that early diagnosis of these symptoms can contribute to improve the care and quality of life of the elderly ${ }^{(5,6)}$.

An important factor influencing the incidence of depressive symptoms among institutionalized elderly is the deterioration of family support and the distance of family members, which may cause situations of loneliness and affective isolation as well as feelings of abandonment and emptiness ${ }^{(7)}$.

A study carried out in Brazil indicates that the visits of family members decrease as the time in institutions increases, showing that family ties become fragile over time ${ }^{(8)}$.

In the United States and Great Britain, the government has acknowledged the involvement of the family in caring for the institutionalized elderly since 1987, and the Australian government emphasized the fact that families can and should contribute to the independence of elderly nursing home residents to preserve their privacy, dignity and their leisure activities ${ }^{(9)}$.

There are family systems that are functional and others are dysfunctional. The functional family group is able to respond to conflict and crisis situations with a certain emotional stability. In this case, the family is a unit of support and care ${ }^{(10-11)}$.

In the dysfunctional family, on the other hand, members prioritize individual interests at the expense of the group interests and do not assume their roles within the system $^{(11-12)}$. The way individuals perceive the efficiency and quality of this resource will significantly influence their health status ${ }^{(11)}$.
Therefore, it is necessary to evaluate the family functioning. As a therapeutic resource it is an important tool in helping teams to assist the elderly ${ }^{(10)}$.

Although family functioning is a topic that has already been studied with the elderly, there is still a gap in knowledge about family functioning of elderly residents in long-term nursing homes. This has greater amplitude when related to the influence of family functioning in the prevalence of depressive symptoms among institutionalized elderly since studies in the literature that address this issue are scarce. Thus, there is a need to carry out studies that provide an understanding of the context of the institutionalized elderly not only with regard to physical aspects but also in relation to human and social aspects. Therefore, the aim of this study was to analyze the relationship between depressive symptoms and the family functioning of institutionalized elderly.

\section{METHOD}

This is a descriptive, analytical, cross-sectional study of quantitative character. It was carried out with elderly residents of six Nursing Homes in the city of São Carlos - SP, being three private institutions and three philanthropic. The non-probability technique of convenience sampling was used to select the subjects who participated in the study, in which the sample elements were chosen for convenience according to the inclusion criteria. The inclusion criteria were: aged 60 years or older, residing in a LongTerm Nursing Home of the municipality, providing knowledge about the existence of a family member and not having severe impairment of language or understanding that might interfere with the accuracy of the answers. It was considered as a family member any individual recognized as such in the opinion of the elderly ${ }^{(13)}$.

A total of 225 elderly residents were found in the six institutions studied. Among these, 118 were excluded for not meeting the inclusion criteria of the study. The subjects of this study were 107 elderly in total; 42 men and 65 women.

Data collection began after reading and signing the consent form (CF) and consisted of a structured interview with the institutionalized elderly under the supervision of authorities of the institution. It was carried out between June and December 2010 through individual interviews with the elderly at the premises of the Nursing Homes.

The following instruments were used: a previously prepared instrument for socioeconomic characterization containing data such as gender, age, marital status and family APGAR to assess family functioning, as well as the Geriatric Depression Scale - GDS (version 15) to detect depressive symptoms.

The Family APGAR was developed by Smilkstein in $1978^{(14)}$ and validated for the Brazilian elderly by Duar-
The relationship between depressive symptoms and family functioning in institutionalized elderly Oliveira SC, Santos AA, Pavarini SCI 
te $\mathrm{e}^{(10)}$. It is an instrument consisting of five questions that allow the measurement of family members satisfaction on five components considered basic in the unit and functionality of any family: adaptation, partnership, growth, affection and response capacity. According to the responses, the total score indicates the condition of $\mathrm{fa}$ mily functioning (good functioning with scores between 13 and 20 points; moderate with scores between 9 and 18 points; or high dysfunctioning with scores between 1 and 8 points).

The Geriatric Depression Scale - GDS (Version 15), was developed by Yesavage et al. (1983) and is already validated for use in Brazil ${ }^{(15-16)}$. It consists of 15 dichotomous questions (yes / no). If the final result is five or higher, the depressive signs are then tracked, in which 6 to 10 represent moderate depressive symptoms and, if that score is equal to or greater than 11, it indicates the presence of severe depressive symptoms ${ }^{(16)}$. In the present study, the results of the GDS were dichotomized between elderly without depression or with depressive symptoms in order to facilitate statistical analysis.

Data were analyzed using descriptive and correlational statistics, where the Family APGAR variable was correlated with the Geriatric Depression Scale (GDS) variable, gender and age. The GDS variable was also correlated with the variables gender, age and marital status. Correlations were obtained by Pearson's correlation coefficient and Spearman correlation. The Pearson Chi-Square test was used to study the relationship between the Family APGAR variable and GDS variable. To analyze the association between variables, the crude and adjusted logistic regression was used through the odds ratio, which is a way of measuring the association between the categories of the response variable and the changes in the explanatory variable. The Geriatric Depression Scale was considered a dependent variable and the family dysfunction an independent variable, which for this analysis was subdivided among elderly with depressive symptoms and elderly without depressive symptoms. The outcome was the presence of depressive symptoms. The analysis that compared the means of the categories of depressive symptoms with the total scores of the Family APGAR symptoms was performed using the Kruskal-Wallis test. The tabulated data were presented as graphs or tables. The level of significance was set at $5 \%$.

The recommendations of Resolution No. 196/96, regulated by the National Health Council which deals with research involving humans were followed. This study was approved by the Research Ethics Committee of the Universidade Federal de São Carlos (Process number 268/2010) and data collection was authorized by the Municipal Health Secretariat of the municipality.

\section{RESULTS}

Individual interviews with 107 elderly residents in long-stay nursing homes were conducted. There was a predominance of female elderly (61\%), widowed (48\%) and the average age of these elderly was 77 years, with a standard deviation of 8.43 years. The percentual description of the sociodemographic characteristics of the subjects is shown in Table 1.

Table 1 - Univariate analysis between demographic data and the presence of depressive symptoms in elderly residents in LTNHs - São Carlos, SP, Brazil, 2010

\begin{tabular}{|c|c|c|c|c|c|c|c|c|}
\hline \multirow{2}{*}{ Variable } & \multirow{2}{*}{ Category } & \multirow{2}{*}{$\mathbf{N}$} & \multirow{2}{*}{$\%$} & \multicolumn{2}{|c|}{ With depressive symptoms } & \multicolumn{2}{|c|}{ Without depressive symptoms } & \multirow{2}{*}{$\mathbf{P}$} \\
\hline & & & & $\mathbf{N}$ & $\%$ & $\mathbf{N}$ & $\%$ & \\
\hline \multirow[t]{3}{*}{ Age Group } & 60 to 69 years & 19 & 18 & 11 & 58 & 8 & 42 & \multirow{3}{*}{0.0057} \\
\hline & 70 to 79 years & 40 & 37 & 21 & 52 & 19 & 48 & \\
\hline & 80 years and older & 48 & 45 & 40 & 83 & 8 & 17 & \\
\hline \multirow[t]{2}{*}{ Gender } & Female & 65 & 61 & 45 & 69 & 20 & 31 & \multirow{2}{*}{0.5944} \\
\hline & Male & 42 & 39 & 27 & 64 & 15 & 36 & \\
\hline \multirow[t]{4}{*}{ Marital Status } & Widowed & 48 & 45 & 37 & 77 & 11 & 23 & \multirow{4}{*}{0.0025} \\
\hline & Married & 13 & 12 & 3 & 23 & 10 & 77 & \\
\hline & Single & 30 & 28 & 22 & 73 & 8 & 27 & \\
\hline & Divorced & 16 & 15 & 10 & 62 & 6 & 38 & \\
\hline
\end{tabular}

Regarding the Geriatric Depression Scale, 35 (33\%) participants did not have depressive symptoms and $72(67 \%)$ showed these symptoms. Among those with symptoms, 46 (43\%) had mild depression and $26(24 \%)$ had severe depression. Table 1 also shows the depressive symptoms according to sociodemographic variables. There was statistical correlation between depressive symptoms and the variables age $(\rho=0.0057)$ and marital status $(\rho=0.0025)$.
Regarding the family functioning reported by institutionalized elderly, most had high family dysfunctioning $(57 \%)$, followed by good family functioning (22\%) and moderate family dysfunctioning (21\%).

Family dysfunctioning was higher among the age group of 80 and older (46\%), followed by $38 \%$ of the age group of $70-79$ years and $16 \%$ of the elderly aged up to 69 years. Family dysfunctioning was higher 
among women (57\%) compared to men (43\%) (Table 2). Through the Pearson Chi-Square test, no correlation was found between the Family APGAR and gender
( $p$-value $=0.1045)$ and the Spearman correlation coefficient showed no correlation with the Family APGAR and age $(\rho=-0.5712)$ (Table 2$)$.

Table 2 - Analysis of the association between family functioning according to gender and age group of elderly residents in LTNHs - São Carlos, SP, Brazil, 2010

\begin{tabular}{|c|c|c|c|c|c|c|c|}
\hline \multirow{3}{*}{ Variables } & \multicolumn{4}{|c|}{ Family APGAR } & \multirow{2}{*}{\multicolumn{2}{|c|}{ Total }} & \multirow{3}{*}{$\mathbf{P}$} \\
\hline & \multicolumn{2}{|c|}{ No family dysfunction } & \multicolumn{2}{|c|}{ Family dysfunction } & & & \\
\hline & $\mathbf{N}$ & $\%$ & $\mathbf{N}$ & $\%$ & $\mathbf{N}$ & $\%$ & \\
\hline \multicolumn{8}{|l|}{ Gender } \\
\hline Gender & 18 & 75 & 47 & 57 & 65 & 61 & \multirow{2}{*}{0.1045} \\
\hline Male & 6 & 25 & 36 & 43 & 42 & 39 & \\
\hline \multicolumn{8}{|l|}{ Age Group (years) } \\
\hline 60 to 69 years & 6 & 25 & 13 & 16 & 19 & 18 & \multirow{3}{*}{0.5712} \\
\hline 70 to 79 years & 8 & 33 & 32 & 38 & 40 & 37 & \\
\hline 80 years and older & 10 & 42 & 38 & 46 & 48 & 45 & \\
\hline
\end{tabular}

In relation to depressive symptoms and family functioning, it was found that most elderly patients with depressive symptoms also had family dysfunctioning (84\%) (Table 3 ). With the Pearson chi-square test, a statistically significant association between the Family APGAR and the GDS (p-value $=0.002$ ) was found. The elderly with depressive symptoms had more dysfunctional families hence depression was associated with family dysfunctioning (Table 3).

Table 3 - Analysis of the association between family functioning and depressive symptoms of elderly residents in LTNH - São Carlos, SP, Brazil, 2010

\begin{tabular}{|c|c|c|c|c|c|}
\hline \multirow{3}{*}{ Geriatric Depression Scales (GDS) } & \multicolumn{4}{|c|}{ Family APGAR } & \multirow{3}{*}{$\mathbf{P}$} \\
\hline & \multicolumn{2}{|c|}{ With family dysfunction } & \multicolumn{2}{|c|}{ No family dysfunction } & \\
\hline & $\mathbf{N}$ & $\%$ & $\mathbf{N}$ & $\%$ & \\
\hline Presence of depressive symptoms & 70 & 84 & 02 & 08 & \multirow{2}{*}{0.002} \\
\hline Absence of depressive symptoms & 13 & 16 & 22 & 92 & \\
\hline Total & 83 & 100 & 24 & 100 & \\
\hline
\end{tabular}

The comparison analysis of the means that compared the categories in relation to the level of manifestation of depressive symptoms with the total scores of the Family APGAR using Kruskal-Wallis test did not identify significant differences between the groups with moderate and severe symptoms $(p=0.900)$. This analysis showed that both the groups with moderate depressive symptoms and severe depressive symptoms had significant greater family dysfunctioning ( $p=0.009$ and $p=0.017$ respectively) when compared to the elderly who did not have depressive symptoms (Figure 1).

Relationship between the Family APGAR and GDS

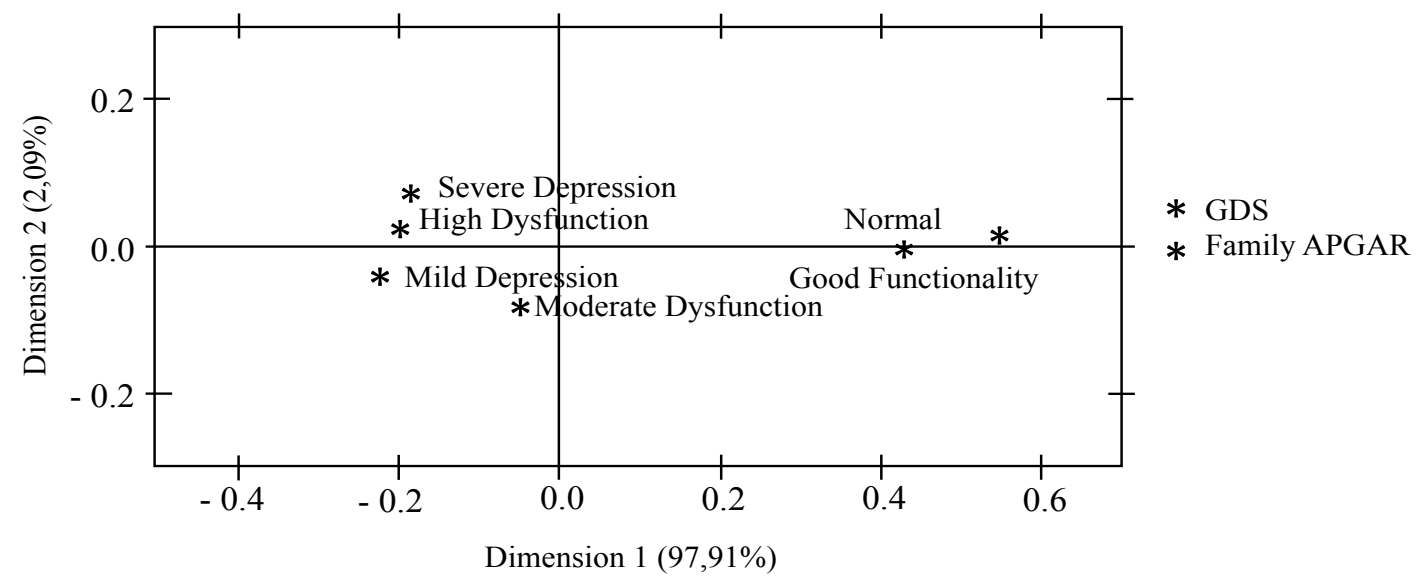

Figure 1 - Presentation of the relationship between the Family APGAR and GDS - São Carlos, SP, Brazil, 2010

To study the impact of the family dysfunction variable on depressive symptoms the model of multiple logistic regression was used. In this model it was found that the family dysfunction variable was associated with depressive symptoms. Through the odds ratio, it was observed that individuals with family dysfunctioning are 6,125 times more likely to experience depressive symptoms. So the family dysfunction variable is highly significant to explain the presence of depressive symptoms.
The relationship between depressive symptoms and family functioning in institutionalized elderly Oliveira SC, Santos AA, Pavarini SCI 


\section{DISCUSSION}

Our results show that there was a predominance of institutionalized women, which is in line with other stu$\operatorname{dies}^{(12,17)}$. One of the reasons given to justify the prevalence of institutionalized elderly women was the fact that men have a greater chance of being cared for by women. The main source of support to elderly men were their spouses and, for women, their children ${ }^{(12)}$. Our results revealed the predominance of elderly in the age group of 80 years and older. These findings corroborate the literature that highlights the prevalence of institutionalized elderly increasingly elderly ${ }^{(7-8,17)}$. The age group of 80 years and older is considered a potential risk factor for institutionalization, mainly due to the higher risk for chronic conditions, resulting in the prevalence of dependent elderly as a consequence ${ }^{(17)}$.

There was statistical correlation between depressive symptoms and the age variable and the majority of elderly with depressive symptoms was in the age group of above 80 years. According to the literature, it is important to pay attention to the age in which the condition of depression appears because there is evidence that the symptoms of depression are more common in older elderly with comorbidities that trigger some degree of dependence ${ }^{(4,18)}$. With regard to marital status, the findings of this study showed that the majority of institutionalized elderly were widowed and unmarried. These findings are in agreement with the findings of a study on social support to institutionalized elderly carried out in Colombia, in which $48 \%$ of institutionalized elderly were single, followed by widowed (30\%). Only $11 \%$ of institutionalized elderly were divorced and $10 \%$ were married ${ }^{(19)}$. There was statistical correlation between depressive symptoms and the marital status variable. Similar findings were found in a study that aimed to examine the prevalence of depression in institutionalized elderly. The results showed that the marital status variable was associated with depression, and most institutionalized elderly with depression were single or widowed ${ }^{(20)}$.

Depressive symptoms among institutionalized elderly was also observed in a study that aimed to assess the presence of depression among elderly residents in long-stay nursing homes and elderly living in their homes, in a community in the northeastern region of Brazil. The results showed that the prevalence of depressive symptoms was higher among institutionalized elderly and, according to the authors, they can be aggravated by the development of functional dependence, presence of diseases and by the difficulty of health professionals and caregivers in recognizing such depressive symptoms among institutionalized elderly ${ }^{(21)}$.

Another study on depression in institutionalized elderly carried out in the United States showed that the percentage of those with depressive symptoms was higher among the newly admitted elderly as $54 \%$ of them were diagnosed with depression during the first year of institutionalization, $32 \%$ upon admission in the institution and $21 \%$ after the first year of institutionalization. This data can be correlated to the fact that this first year is characterized by changes and adaptations. Despite some flexible activities, at the same time the institution usually has a rigid organization of meal times, planning of tours and family gatherings, what causes deterioration of family support, among other activities(6). Another factor that may explain the onset of depression in the early months of residence in an institution is the presence of a feeling of hope by the institutionalized elderly that their families will take care of them when the right time comes, especially for those who had children ${ }^{(22)}$.

Regarding family functioning, our results showed that the institutionalized elderly have recognized their families as dysfunctional. This finding is worrisome because the presence of a functional family structure is essential for the well-being and quality of life of the elderly ${ }^{(23)}$. The results of the present study differ from previous studies, in which there is a predominance of good family functioning ${ }^{(24-26)}$. This can be explained by the different contexts in which the studies were carried out, ie, the predominance of good family functioning occurs among communitydwelling elderly ${ }^{(24-26)}$.

Considering depression together with family relationships of institutionalized elderly, it was found that those with depressive symptoms were more dysfunctional in relation to their families therefore depression was associated with family dysfunctioning. Individuals with family dysfunction were 6,125 times more likely to show depressive symptoms. A study carried out in Taiwan with 90 elderly residents of 16 LTNHs aimed at evaluating the long-term effectiveness of an intervention program through videoconferencing with family members of institutionalized elderly ${ }^{(27)}$. The author concluded that the videoconferencing program that promoted family socialization had a protective effect in relation to depressive symptoms and loneliness of institutionalized elderly ${ }^{(27)}$.

In this context, it is understood that the family and the elderly should be the focus of the multidisciplinary team of workers in a $\mathrm{LTNH}^{(2)}$. Nursing, as a profession of care, is required as part of the multidisciplinary care to institutionalized elderly, which should fully assist the elderly, taking into consideration the biopsychosocial and spiritual aspects experienced by them, promoting humanized, full and individualized care in order to accommodate the elderly and their families in the $\mathrm{LTNH}^{(28)}$.

However, the nursing staff finds it difficult to integrate the family in the life context of institutionalized elderly because they are generally absent, showing no interest in joining with the institution ${ }^{(28)}$. At the same time these professionals recognize that any form of participation exercised by the family in the institutionalization process is extremely important because it somehow helps minimizing the neediness of the elderly and consequently decreases the risk of developing depression symptoms ${ }^{(29)}$. Trying to motivate families to be more active in the care for the elderly, establishing ties among the elderly, their families 
and the professionals should be one of the major goals in the care of geriatric nursing ${ }^{(29)}$.

Thus, we observe that the literature shows that harmed family relationships are strongly associated with the presence of depressive symptoms in institutionalized elderly ${ }^{(5-6,21,27)}$. Therefore, there is a great need to investigate the role of family functioning during the process of geriatric depression ${ }^{(30)}$.

\section{CONCLUSION}

In this study, it was found that the majority of elderly had high family dysfunctioning (57\%), followed by good family functioning (22\%) and moderate family dysfunctioning (21\%). The presence of depressive symptoms was higher among the elderly with family dysfunctioning. The results also showed that there was significant correlation between the Family APGAR and depressive symptoms. In multiple logistic regression analysis we concluded that the institutionalized elderly with dysfunctional families were more likely to have depressive symptoms.

Despite the limitations of the study (relatively small sample size and the fact that it was obtained by the technique of convenience sampling), it is extremely important to consider the influence of family functioning in the prevalence of depressive symptoms among

\section{REFERENCES}

1. Banco Mundial. Envelhecendo em um Brasil mais velho [Internet]. Washington; 2011 [citado 2012 nov. 13]. Disponível em: http://siteresources.worldbank.org/BRAZILINPOREXTN/ Resources/3817166- 1302102548192/Envelhecendo_Brasil_ Sumario_Executivo.pdf

2. Creutzberg M, Gonçalves LHT, Sobottka EA, Ojeda BS. Longterm care institutions for elders and the health system. Rev Latino Am Enferm. 2007;15(6):1144-9.

3. Thakur M, Blazer DG. Depression in long-term care. J Am Med Dir Assoc. 2008; 9(2):82-7.

4. World Health Organization (WHO). The World Health Report 2001 - Mental health: new understanding, new hope. Geneva; 2001.

5. Salgueiro A, Martinez-García R, Molinero O, Márquez S. Physical activity, quality of life and symptoms of depression in community-dwelling and institutionalized older adults. Arch Gerontol Geriatr. 2011;53(2):152-7.

6. Hoover DR, Siegel M, Lucas J, Kalay E, Gaboda D, Devanand $D P$, et al. Depression in the first year of stay for elderly long term nursing home residents in the U.S.A. Int Psychogeriatr. 2010;22(7):1161-71. institutionalized elderly, in the sense of satisfactorily directing health actions for this population. Also in this sense, a reflection on the relationship between depressive symptoms and family functioning of institutionalized elderly meets the research proposals found in the $\mathrm{Na}$ tional Agenda of Priorities in Health Research of 2008. The agenda propositions are to respect national and regional health needs, increase the selective induction for producing knowledge, material and procedural goods in priority areas for the development of social policies. One of its priority themes covers the issue of elderly health and this involves studies on long-term care and family organization against aging.

Interventions that take into account the factors associated with family functioning in the prevalence of depressive symptoms should be planned since depression is a common and highly prevalent disease among institutionalized elderly and the early diagnosis can help to improve the care and quality of life of the elderly.

Considering that Brazilian studies on this topic are scarce, it is imperative that nursing embraces that knowledge, since the elderly with depressive symptoms and dysfunctional families demand much care of health professionals. Improving family functioning may improve the prognosis of geriatric depression. After all, understanding the family context of institutionalized elderly can contribute to a more appropriate gerontological nursing care.

7. Marinho PEM, Melo KP, Apolinário AD, Bezerra E, Freitas J, Melo DM, et al. Undertreatment of depressive symptomatology in the elderly living in long stay institutions and in the community in Brazil. Arch Gerontol Geriatr. 2010;50(1):151-5.

8. Perlini NMOG, Leite MT, Furini AC. Em busca de uma instituição para as pessoas idosas morar: motivos apontados por familiares. Rev Esc Enferm USP. 2007; 41(2):229-36.

9. Australian Government. Department of Health. Charter of residents rights and responsibilities: a document outlining aged care residents rights and responsibilities [Internet]. [cited 2012 Sept 20]. Available from: http://www.health.gov. au/internet/main/publishing.nsf/content/ageing-publicatresicharter.htm

10. Paiva ATG, Bessa MEP, Moraes GLA, Silva MJ, Oliveira RDP, Soares AMG. Avaliação da funcionalidade de famílias com idosos. Cogitare Enferm. 2011; 16(1):22-8.

11. Gonçalves LHT, Costa MAM, Martins MM, Nassar SM, Zunino R. The family dynamics of elder elderly in the context of Porto, Portugal. Rev Latino Am Enferm. 2011;19(3):458-66.

12. Falcão DVS. A família e o idoso: desafios da contemporaneidade. 2a ed. Campinas: Papirus; 2010.
The relationship between depressive symptoms and family functioning in institutionalized elderly Oliveira SC, Santos AA, Pavarini SCI 
13. WrightL M, Leahey M. Enfermeiras e famílias: um guia para avaliação e intervenção na família. 3a ed. São Paulo: Roca; 2002.

14. Smilkstein, G. The Family APGAR: a proposal for a family function test and its use by physicians. J. Fam Pract. 1978;6(6):1231 - 39.

15. Yesavage JA, Brink TL, Rose TL, Lum O, Huang V, Adey $M$, et al. Development and validation of a geriatric depression screening scale: a preliminary report. J Psychiatr Res. 1983;17(1):37-49.

16. Almeida OP, Almeida SA. Confiabilidade da versão brasileira da escala de depressão em geriatria (GDS) versão reduzida. Arq Neuropsiquiatr. 1999;57(2B):421-6.

17. Corteletti IA, Casara MB, Herédia VBM. Idoso asilado: um estudo gerontológico. 2ª ed. Porto Alegre: EDPUCRS; 2010.

18. Carreira L, Botelho MR, Matos PCB, Torres MM, Salci MA. Prevalência de depressão de idosos institucionalizados. Rev Enferm UERJ. 2011;19(2):268-73.

19. Arango DC, Estrada-Restrepo A, Chavarriaga-Maya LM, Segura-Cardona AM, Ordones-Molina J, Osorio-Gómez JJ. Apoyo social dignificante del adulto mayor institucionalizado. Rev Saúde Pública. 2010;12(3):414-24.

20. Carreira L, Botelho MR, Matos PCB, Torres MM, Salci MA. Prevalência de sintomas depressivos em idosos institucionalizados. Rev Enferm UERJ. 2011;19(2):268-73.

21. Marinho PEM, Melo KP, Apolinário AD, Bezerra E, Freitas J, Melo DM, et al. Undertreatment of depressive symptomatology in the elderly living in long stay institutions and in the community in Brazil. Arch Gerontol Geriatr. 2010;50(1):151-5.
22. Silva LR, Vázquez-Garnica EK, Elba K. O cuidado aos idosos: considerações sobre o cuidado não familiar. Texto Contexto Enferm. 2008;17(2):225-31.

23. Wang J, Zhao X. Family functioning and social support for older patients with depression in an urban area of Shanghai, China. Arch Gerontol Geriatr. 2012; 55(3):574-9.

24. Andrade AINPA, Martins RM. Funcionalidade familiar e qualidade de vida dos idosos. Millenium. 2011;40(1):185-99.

25. Santos AA, Pavarini SCl, Barham EJ. Percepção de idosos pobres com alterações cognitivas sobre funcionalidade familiar. Texto Contexto Enferm. 2011;20(1):102-10.

26. Paiva ATG, Bessa MEP, Moraes GLA, Silva MJ, Oliveira RDP, Soares AMG. Avaliação da funcionalidade de famílias com idosos. Cogitare Enferm. 2011;16(1): 22-8.

27. Tsai HH, Tsai YF. Changes in depressive symptoms, social support, and loneliness over 1 year after a minimum 3-month videoconference program for older nursing home residents. J Med Internet Res. 2011;13(4):e93.

28. Piexak DR, Freitas PH, Backes DS, Moreschi C, F erreira CLL, Souza MHT. Percepção de profissionais de saúde em relação ao cuidado a pessoas idosas institucionalizadas. Rev Bras Geriatr Gerontol. 2012;15(2):201-8.

29. Andrade ACA, Lima FRA, Silva LFA, Santos SSC. Depressão em idosos de uma instituição de longa permanência (ILPI): proposta de ação de enfermagem. Rev Gaúcha Enferm. 2005;26(1):57-66.

30. Ying-Yueh T, Show-Chuan S, Hong-Jer C, Li I. Factors Associated with Depressive Mood in the Elderly Residing at the Long-Term Care Facilities. Int J Gerontol. 2012; 6(1):5-10.

\section{Acknowledgements}

We appreciate the financial support of the Coordenação de Aperfeiçoamento de Pessoal de Nível Superior (CAPES). 